\title{
Yielding and fruit quality of Lithuanian sweet cherry cultivars grown under the climatic and soil conditions of Warmia
}

\author{
Anna Bieniek', Zdzistaw Kawecki', \\ Jan Kopytowski ${ }^{\prime}$, Jerzy Zielenkiewicz ${ }^{2}$ \\ ${ }^{1}$ Department of Horticulture \\ University of Warmia and Mazury in Olsztyn \\ Prawocheńskiego 21, 10-957 Olsztyn, Poland \\ ${ }^{2}$ Experimental and Production Institute "Pozorty" Spółka z o.o. \\ Juliana Tuwima 19, 10-747 Olsztyn, Poland \\ e-mail: anna.bieniek@uwm.edu.pl
}

\begin{abstract}
In 2006-2008, yielding was determined and biometric measurement as well as chemical analysis was carried out for five Lithuanian sweet cherry cultivars, 'Agila', 'Seda', 'Vasare', 'Ventenue', and 'Jurgita', and two cultivars commonly grown in Poland, 'Ulster' and 'Burlat'. Trees grafted on Mazzard seedlings were planted in 2002 in the orchard of the Pozorty Experimental and Production Institute in the village of Łegajny near Olsztyn. The highest mean yield for the tested cultivars was obtained in 2008, while the lowest was in 2007, when the highest ground frosts were recorded during the cherry blossoming period. During the three years of research, the highest mean yield for the Lithuanian sweet cherry cultivars was established for the 'Vasare' cultivar, which together with the 'Burlat' cultivar made a homogenous group of the highest values. The mean fruit weight of the Lithuanian cultivars was lower than in the case of 'Burlat' and 'Ulster', while the largest fruit amongst the Lithuanian cultivars were recorded for 'Jurgita' and 'Agila'. The chemical composition analysis of fruit revealed significant differences both between the cultivars and the years of the research. The fruits of the studied cultivars accumulated the lowest amounts of total saccharides and vitamin $\mathrm{C}$ in the coolest year under analysis, 2007. The highest mean of total saccharide content was recorded for fruit of the 'Vasare' and 'Seda' cultivars. Fruit of the 'Agila' cultivar accumulated the highest amounts of organic acids and vitamin C.
\end{abstract}

Key words: sweet cherry, Lithuanian cultivars, yield, chemical composition of fruits, morphology of fruits

\section{INTRODUCTION}

The possibility of selecting new cultivars of sweet cherry originating from the coldest areas of climates similar to the climatic conditions of Poland is a chance for their successful cultivation in regions with significant temperature drops. Most genotypes of sweet cherries cultivated so far have been of German, French and American origin. The cultivation of sweet cherry cultivars in Lithuania began in the early $20^{\text {th }}$ century, and it was then that the first Lithuanian cultivars were created
(Stanys et al. 2008). The expectations of Polish fruit growers are directed towards an improvement in the cultivation and production of frost-resistant cultivars. Since Lithuanian sweet cherry cultivars are less susceptible to low temperatures, their cultivation was undertaken in Warmia, where the climatic condition are similar to those prevailing in Lithuania. The literature published so far lacks information on the cultivation and fruit quality of Lithuanian cultivars in Poland. An adaptation of cultivars of Lithuanian origin to be grown in 
northeastern Poland indicates the possibility of obtaining highly frost-resistant sweet cherries.

The aim of this research was to assess the yield and fruit quality of five Lithuanian cultivars as compared to two native cultivars, 'Burlat' and 'Ulster', grafted on Mazzard seedlings, cultivated under the climatic and soil conditions of Warmia in 2006-2008.

\section{MATERIAL AND METHODS}

Five Lithuanian sweet cherry cultivars, 'Agila', 'Seda', 'Vasare', 'Ventenue', and 'Jurgita', and two commonly cultivated in Poland, 'Ulster' and 'Burlat', were planted in 2002 in the orchard of the Pozorty Experimental and Production Institute, located in the village of Legajny near Olsztyn. The trees were grafted on Mazzard seedlings. The experiment was established in two rows, in six replications (six trees per replication), preserving $3 \mathrm{~m} \times 4 \mathrm{~m}$ spacing.

The experimental plot, with a total area of nearly three acres, was established on podzolic soil, cerealfodder strong complex, class III $b$. The cultivation, fertilisation and plant protection procedures were performed according to the framework schedule.

In 2006-2008, the yielding of the tested sweet cherry cultivars was determined, biometrical measurements were taken and chemical analysis of the fruit were carried out. Morphological traits were estimated on the basis of a sample of 100 fruits for replications. Thelaboratorysampleusedforanalysing the chemical composition of fruits for each cultivar was $0.5 \mathrm{~kg}$. The results obtained were presented as a mean average of three chemical analyses carried out simultaneously. Laboratory analyses concerned the content of the following components: vitamin $\mathrm{C}$ (PN-90/A-75101/11), monosaccharides and total saccharides (PN-90/A-75101/07), organic acids
(PN-90/A-75/101/04), and dry matter, using a drying method at $105^{\circ} \mathrm{C}$ until a solid mass was obtained.

The results were statistically analysed using variation analysis according to the arrangement of the experiment. The differences between means were assessed by applying the t-Tukey test, at a significance level of $1 \%$ for chemical analyses concerning the content of organic compounds and $5 \%$ for other features.

\section{RESULTS AND DISCUSSION}

Statistical analysis of the examined features of sweet cherry in 2006-2008 revealed significant differences, both between cultivars and the years of research (Tabs 1-4).

During the three years of research, the highest mean yield for Lithuanian sweet cherry cultivars was established for the 'Vasare' cultivar, which together with the 'Burlat' cultivar made a homogenous group of the highest values. The lowest yield of sweet cherry fruit in the research under analysis was obtained in 2007 (Tab. 1). Significant differences in yield between the research years in the group of older trees indicate the great impact of weather conditions on the fruit yield of trees (Wociór 2008). The significant yield decrease in 2007 was the result of spring ground frosts. During the first days of May, ground frosts in Olsztyn ranged from -7.1 to $-1.0^{\circ} \mathrm{C}$. In the second half of May, as many as seven days with ground frost were recorded, which in the two last days of that month reached -1.4 and $-3.5^{\circ} \mathrm{C}$ (Bieniek et al. 2009). Spring ground frosts damaged most flower buds and fruit ovaries, which resulted in a decrease in fruit yield. The Lithuanian cultivars in the year under discussion were characterised by a higher yield as compared to 'Burlat' and 'Ulster', which could prove a higher resistance of their flowers

Table 1. A comparative analysis of sweet cherry cultivar yields in the years 2006-2008

\begin{tabular}{|c|c|c|c|c|}
\hline \multirow[t]{2}{*}{ Cultivar } & \multicolumn{3}{|c|}{$\begin{array}{c}\text { Yield } \\
\left(\mathrm{kg} \mathrm{tree}^{-1}\right)\end{array}$} & \multirow[t]{2}{*}{ Mean of 3 years } \\
\hline & 2006 & 2007 & 2008 & \\
\hline Agila & $5.7 \mathrm{f}^{*}$ & $4.0 \mathrm{~cd}$ & $6.5 \mathrm{~g}$ & $5.4 \mathrm{~b}$ \\
\hline Seda & $7.5 \mathrm{~h}$ & $3.5 \mathrm{c}$ & $7.5 \mathrm{~h}$ & $6.2 \mathrm{c}$ \\
\hline Vasare & $6.5 \mathrm{~g}$ & $4.5 \mathrm{de}$ & $10.3 \mathrm{j}$ & $7.1 \mathrm{~d}$ \\
\hline Ventenue & $5.5 \mathrm{f}$ & $5.5 \mathrm{f}$ & $5.1 \mathrm{ef}$ & $5.4 \mathrm{~b}$ \\
\hline Jurgita & $5.5 \mathrm{f}$ & $1.5 \mathrm{ab}$ & $6.7 \mathrm{~g}$ & $4.6 \mathrm{a}$ \\
\hline Ulster & $2.0 \mathrm{~b}$ & $1.5 \mathrm{ab}$ & 13.51 & $5.7 \mathrm{~b}$ \\
\hline Burlat & $8.5 \mathrm{i}$ & $1.0 \mathrm{a}$ & $12.2 \mathrm{k}$ & $7.2 \mathrm{~d}$ \\
\hline Mean of a year & $5.9 \mathrm{~b}$ & $3.1 \mathrm{a}$ & $8.8 \mathrm{c}$ & - \\
\hline
\end{tabular}

*The values denoted with the same letters are not significantly different at $p=0.05$ 
to freezing. The level of sweet cherry yielding in Poland is still unsatisfactory, amounting to about 4-6 t ha-1 (Makosz 1999). The marketable yield of the tested cultivars was low, ranging from $3.1 \mathrm{~kg}$ per tree, or $2.58 \mathrm{t}$ as converted per hectare in 2007 , to $8.8 \mathrm{~kg}$ per tree ( $7.33 \mathrm{t}$ per hectare) in 2008 (Tab. 1). On the other hand, many researchers report that an increase in yield is often accompanied by a smaller fruit size (Whiting and Ophardt 2005, Whiting et al. 2006, Bennewitz et al. 2010). Cultivars with large fruits have a very high marketable value. The mean fruit weight of the examined sweet cherry cultivars was the highest in 2006, while the lowest mean was recorded in 2007 (Tab. 2). The 'Burlat' cultivar produced the highest fruit weight during the three years of research, followed by 'Ulster'. The weight of the Lithuanian cultivars ranged from $3.78 \mathrm{~g}$ ('Vasare') to $4.39 \mathrm{~g}$ ('Jurgita'). The 'Agila' cultivar was characterised by the lowest mean fruit length while the 'Jurgita' cultivar with the highest values. The highest length and width of fruit was observed for the 'Burlat' and 'Ulster' cultivars. Fruits of the 'Vasare' cultivar were characterised by the lowest width. The average fruit weight of the 'Burlat' and 'Ulster' cultivars published in the literature ranges from 6.5 to $7 \mathrm{~g}$ (Rozpara 1999). Sitarek (2004) reports the weight of fruits from 10-year-old trees of the 'Burlat' cultivar as ranging from 7.1 to $7.8 \mathrm{~g}$, depending on the rootstock used. Rozpara and Grzyb (2006) report the weight of fruits of the 'Burlat' cultivar grafted on Mazzard seedlings as between 6.98 to $7.27 \mathrm{~g}$. In the present research, it ranged from $5.31 \mathrm{~g}$ to $7.52 \mathrm{~g}$. Smaller fruits were also obtained for the 'Ulster' cultivar, for which the weight provided by Rozpara $(1999,2000)$ was 6.5$7.0 \mathrm{~g}$, while fruits obtained in this study weighed

Table 2. Fruit morphology of sweet cherry cultivars in the years 2006-2008

\begin{tabular}{|c|c|c|c|c|c|c|c|c|c|c|c|c|}
\hline \multirow{2}{*}{ Cultivar } & \multicolumn{4}{|c|}{$\begin{array}{l}\text { Weight } \\
\text { (g) }\end{array}$} & \multicolumn{4}{|c|}{$\begin{array}{l}\text { Length } \\
(\mathrm{cm})\end{array}$} & \multicolumn{4}{|c|}{$\begin{array}{l}\text { Width } \\
\text { (cm) }\end{array}$} \\
\hline & 2006 & 2007 & 2008 & $\begin{array}{c}\text { Mean of } \\
3 \text { years }\end{array}$ & 2006 & 2007 & 2008 & $\begin{array}{c}\text { Mean of } \\
3 \text { years }\end{array}$ & 2006 & 2007 & 2008 & $\begin{array}{c}\text { Mean of } \\
3 \text { years }\end{array}$ \\
\hline Agila & $4.58 \mathrm{hi}^{*}$ & $4.30 \mathrm{ef}$ & $4.38 \mathrm{fg}$ & $4.42 \mathrm{~d}$ & $1.63 \mathrm{a}$ & $1.72 \mathrm{a}-\mathrm{c}$ & $1.64 \mathrm{ab}$ & $1.66 \mathrm{a}$ & $1.90 \mathrm{c}-\mathrm{g}$ & $1.95 \mathrm{c}-\mathrm{g}$ & $1.87 \mathrm{~b}-\mathrm{f}$ & $1.91 \mathrm{bc}$ \\
\hline Seda & $4.07 \mathrm{~cd}$ & $4.16 \mathrm{de}$ & $4.64 \mathrm{i}$ & $4.29 \mathrm{c}$ & $1.71 \mathrm{a}-\mathrm{c}$ & $1.80 \mathrm{c}-\mathrm{f}$ & $1.75 \mathrm{a}-\mathrm{d}$ & $1.75 \mathrm{~b}$ & $1.84 \mathrm{a}-\mathrm{d}$ & $2.00 \mathrm{e}-\mathrm{h}$ & $2.04 \mathrm{e}-\mathrm{h}$ & $1.96 \mathrm{~cd}$ \\
\hline Vasare & $4.40 \mathrm{f}-\mathrm{h}$ & $3.22 \mathrm{a}$ & $3.73 \mathrm{~b}$ & $3.78 \mathrm{a}$ & $1.76 \mathrm{~b}-\mathrm{e}$ & $1.70 \mathrm{a}-\mathrm{c}$ & $1.82 \mathrm{c}-\mathrm{g}$ & $1.76 \mathrm{~b}$ & $1.85 \mathrm{~b}-\mathrm{e}$ & $1.73 \mathrm{ab}$ & $1.81 \mathrm{a}-\mathrm{c}$ & $1.80 \mathrm{a}$ \\
\hline Ventenue & $4.53 \mathrm{~g}-\mathrm{i}$ & $3.04 \mathrm{a}$ & $4.15 \mathrm{c}-\mathrm{e}$ & $3.91 \mathrm{~b}$ & $1.67 \mathrm{ab}$ & $1.67 \mathrm{ab}$ & $1.89 \mathrm{e}-\mathrm{h}$ & $1.74 \mathrm{~b}$ & $2.00 \mathrm{e}-\mathrm{h}$ & $1.70 \mathrm{a}$ & $1.83 \mathrm{a}-\mathrm{c}$ & $1.84 \mathrm{ab}$ \\
\hline Jurgita & $5.10 \mathrm{~d}$ & $3.95 \mathrm{c}$ & $4.13 \mathrm{c}-\mathrm{e}$ & $4.39 \mathrm{~d}$ & $1.88 \mathrm{~d}-\mathrm{g}$ & $1.85 \mathrm{~d}-\mathrm{g}$ & $1.76 \mathrm{~b}-\mathrm{e}$ & $1.83 \mathrm{c}$ & $1.99 \mathrm{e}-\mathrm{i}$ & $1.99 \mathrm{e}-\mathrm{i}$ & $1.93 \mathrm{c}-\mathrm{g}$ & $1.97 \mathrm{~d}$ \\
\hline Ulster & 5.801 & 5.671 & $4.62 \mathrm{i}$ & $5.36 \mathrm{e}$ & $1.98 \mathrm{~h}-\mathrm{j}$ & $2.06 \mathrm{j}$ & $1.93 \mathrm{~g}-\mathrm{i}$ & $1.99 \mathrm{~d}$ & $2.18 \mathrm{gh}$ & $2.13 \mathrm{fg}$ & $1.98 \mathrm{~d}-\mathrm{h}$ & $2.10 \mathrm{e}$ \\
\hline Burlat & $7.52 \mathrm{n}$ & $5.31 \mathrm{k}$ & $6.53 \mathrm{~h}$ & $6.45 \mathrm{f}$ & $2.10 \mathrm{j}$ & $2.05 \mathrm{ij}$ & $2.25 \mathrm{k}$ & $2.13 \mathrm{e}$ & $2.29 \mathrm{~h}$ & $2.12 \mathrm{e}-\mathrm{g}$ & $2.10 \mathrm{e}-\mathrm{i}$ & $2.17 \mathrm{f}$ \\
\hline $\begin{array}{l}\text { Mean } \\
\text { of a year }\end{array}$ & $5.14 \mathrm{c}$ & $3.95 \mathrm{a}$ & $4.60 \mathrm{~b}$ & - & $1.82 \mathrm{a}$ & $1.84 \mathrm{ab}$ & $1.86 \mathrm{~b}$ & - & $2.01 \mathrm{c}$ & $1.95 \mathrm{~b}$ & $1.94 \mathrm{a}$ & - \\
\hline
\end{tabular}

*The values denoted with the same letters are not significantly different at $\mathrm{p}=0.05$

Table 3. The content of dry matter, total saccharides and monosaccharides in the fruits of sweet cherry cultivars in the years 2006-2008

\begin{tabular}{|c|c|c|c|c|c|c|c|c|c|c|c|c|}
\hline \multirow{3}{*}{ Cultivar } & \multicolumn{4}{|c|}{$\begin{array}{c}\text { Dry matter } \\
(\%)\end{array}$} & \multicolumn{4}{|c|}{$\begin{array}{c}\text { Total saccharides } \\
(\%)\end{array}$} & \multicolumn{4}{|c|}{$\begin{array}{c}\text { Monosaccharides } \\
(\%)\end{array}$} \\
\hline & \multicolumn{12}{|c|}{ Experimental years } \\
\hline & 2006 & 2007 & 2008 & $\begin{array}{c}\text { Mean of } \\
3 \text { years }\end{array}$ & 2006 & 2007 & 2008 & $\begin{array}{c}\text { Mean of } \\
3 \text { years }\end{array}$ & 2006 & 2007 & 2008 & $\begin{array}{c}\text { Mean of } \\
3 \text { years }\end{array}$ \\
\hline Agila & $13.83 \mathrm{a}^{*}$ & $13.66 \mathrm{a}$ & $15.82 \mathrm{de}$ & $14.44 \mathrm{a}$ & $9.45 \mathrm{gh}$ & $8.25 \mathrm{e}$ & $9.05 \mathrm{f}$ & $8.92 \mathrm{~d}$ & $3.33 \mathrm{f}$ & $3.56 \mathrm{~g}$ & $5.84 \mathrm{~h}$ & $4.24 \mathrm{c}$ \\
\hline Seda & $16.74 \mathrm{f}$ & $15.08 \mathrm{c}$ & $16.11 \mathrm{e}$ & $15.98 \mathrm{c}$ & $10.18 \mathrm{ij}$ & $4.03 \mathrm{f}$ & $10.88 \mathrm{k}$ & $8.36 \mathrm{~b}$ & $3.36 \mathrm{f}$ & $2.71 \mathrm{a}$ & $6.41 \mathrm{ij}$ & $4.16 \mathrm{~b}$ \\
\hline Vasare & $17.30 \mathrm{~h}$ & $16.11 \mathrm{e}$ & $15.08 \mathrm{c}$ & $16.16 \mathrm{~d}$ & $9.41 \mathrm{f}-\mathrm{h}$ & $9.90 \mathrm{hj}$ & $10.70 \mathrm{j}$ & $10.00 \mathrm{e}$ & $3.22 \mathrm{ef}$ & $2.94 \mathrm{bc}$ & $6.27 \mathrm{~h}$ & $4.14 \mathrm{~b}$ \\
\hline Ventenue & $19.32 \mathrm{k}$ & $16.88 \mathrm{fg}$ & $15.53 \mathrm{~d}$ & $17.24 \mathrm{f}$ & $9.45 \mathrm{gh}$ & $5.40 \mathrm{~cd}$ & $10.36 \mathrm{j}$ & $8.40 \mathrm{~b}$ & $3.31 \mathrm{f}$ & $3.03 \mathrm{~cd}$ & $6.78 \mathrm{k}$ & $4.37 \mathrm{~d}$ \\
\hline Jurgita & $14.85 \mathrm{bc}$ & $17.44 \mathrm{~h}$ & $15.86 \mathrm{e}$ & $16.05 \mathrm{~cd}$ & $9.47 \mathrm{gh}$ & $5.18 \mathrm{c}$ & $10.80 \mathrm{k}$ & $8.48 \mathrm{~b}$ & $3.10 \mathrm{de}$ & $3.23 \mathrm{ef}$ & $5.74 \mathrm{~h}$ & $4.02 \mathrm{a}$ \\
\hline Ulster & $17.17 \mathrm{gh}$ & $15.08 \mathrm{c}$ & $18.14 \mathrm{i}$ & $16.80 \mathrm{e}$ & $9.70 \mathrm{gh}$ & $5.58 \mathrm{~d}$ & $10.92 \mathrm{k}$ & $8.73 \mathrm{c}$ & $3.15 \mathrm{de}$ & $3.51 \mathrm{~g}$ & $6.44 \mathrm{j}$ & $4.37 \mathrm{~d}$ \\
\hline Burlat & $18.98 \mathrm{j}$ & $14.78 \mathrm{~b}$ & $13.58 \mathrm{a}$ & $15.78 \mathrm{~b}$ & $9.28 \mathrm{fg}$ & $3.41 \mathrm{a}$ & $11.02 \mathrm{k}$ & $7.90 \mathrm{a}$ & $2.84 \mathrm{ab}$ & $3.10 \mathrm{de}$ & $6.43 \mathrm{j}$ & $4.12 \mathrm{~b}$ \\
\hline $\begin{array}{l}\text { Mean } \\
\text { of a year }\end{array}$ & $16.88 \mathrm{c}$ & $15.58 \mathrm{a}$ & $15.73 \mathrm{~b}$ & - & $9.56 \mathrm{~b}$ & $5.96 \mathrm{a}$ & $10.53 \mathrm{c}$ & - & $3.19 \mathrm{a}$ & $3.15 \mathrm{a}$ & $6.27 \mathrm{~b}$ & - \\
\hline
\end{tabular}

*The values denoted with the same letters are not significantly different at $\mathrm{p}=0.01$ 
Table 4. The content of organic acids and vitamin C in the fruits of sweet cherry cultivars in the years 2006-2008

\begin{tabular}{|c|c|c|c|c|c|c|c|c|}
\hline \multirow{3}{*}{ Cultivar } & \multicolumn{4}{|c|}{$\begin{array}{c}\text { Organic acids } \\
(\%)\end{array}$} & \multicolumn{4}{|c|}{$\begin{array}{c}\text { Vitamin C } \\
\left(\mathrm{mg} 100 \mathrm{~g}^{-1}\right)\end{array}$} \\
\hline & \multicolumn{8}{|c|}{ Experimental years } \\
\hline & 2006 & 2007 & 2008 & $\begin{array}{c}\text { Mean of } 3 \\
\text { years }\end{array}$ & 2006 & 2007 & 2008 & $\begin{array}{c}\text { Mean of } 3 \\
\text { years }\end{array}$ \\
\hline Agila & 0.97 ef* & $1.03 \mathrm{~d}-\mathrm{f}$ & $1.20 \mathrm{f}$ & $1.07 \mathrm{c}$ & $9.48 \mathrm{k}$ & $7.56 \mathrm{~h}$ & $7.41 \mathrm{~h}$ & 8.15 e \\
\hline Seda & $0.46 \mathrm{ab}$ & $0.56 \mathrm{a}-\mathrm{c}$ & $0.33 \mathrm{a}$ & $0.45 \mathrm{a}$ & $9.07 \mathrm{i}-\mathrm{h}$ & $2.69 \mathrm{a}$ & $9.04 \mathrm{ij}$ & $6.93 \mathrm{c}$ \\
\hline Vasare & $0.56 \mathrm{a}-\mathrm{c}$ & $0.78 \mathrm{a}-\mathrm{d}$ & $0.62 \mathrm{a}-\mathrm{c}$ & $0.65 \mathrm{ab}$ & $8.79 \mathrm{i}$ & $4.62 \mathrm{~d}$ & $8.70 \mathrm{i}$ & $7.37 \mathrm{~d}$ \\
\hline Ventenue & $0.68 \mathrm{a}-\mathrm{c}$ & $0.68 \mathrm{a}-\mathrm{c}$ & $0.74 \mathrm{a}-\mathrm{d}$ & $0.70 \mathrm{~b}$ & $9.39 \mathrm{jk}$ & $5.21 \mathrm{e}$ & $7.30 \mathrm{~h}$ & $7.30 \mathrm{~d}$ \\
\hline Jurgita & $0.52 \mathrm{ab}$ & $0.82 \mathrm{~b}-\mathrm{d}$ & $0.62 \mathrm{a}-\mathrm{c}$ & $0.65 \mathrm{ab}$ & $8.82 \mathrm{i}$ & $5.71 \mathrm{f}$ & $3.30 \mathrm{~b}$ & $5.94 \mathrm{~b}$ \\
\hline Ulster & $0.56 \mathrm{a}-\mathrm{c}$ & $0.81 \mathrm{~b}-\mathrm{d}$ & $0.78 \mathrm{a}-\mathrm{d}$ & $0.72 \mathrm{~b}$ & $9.42 \mathrm{jk}$ & $3.26 \mathrm{~b}$ & $3.99 \mathrm{c}$ & $5.55 \mathrm{a}$ \\
\hline Burlat & $0.50 \mathrm{ab}$ & $0.56 \mathrm{a}-\mathrm{c}$ & $0.58 \mathrm{a}-\mathrm{c}$ & $0.55 \mathrm{ab}$ & $9.45 \mathrm{jk}$ & $6.44 \mathrm{~g}$ & $5.17 \mathrm{e}$ & $7.02 \mathrm{c}$ \\
\hline $\begin{array}{l}\text { Mean } \\
\text { of a year }\end{array}$ & $0.65 \mathrm{a}$ & $0.75 \mathrm{a}$ & $0.70 \mathrm{a}$ & - & $9.20 \mathrm{c}$ & $5.07 \mathrm{a}$ & $6.42 \mathrm{~b}$ & - \\
\hline
\end{tabular}

*The values denoted with the same letters are not significantly different at $\mathrm{p}=0.01$

between 4.62 and $5.8 \mathrm{~g}$. The fruit weight obtained from the tested Lithuanian cultivars was smaller than the values provided in the Lithuanian literature (Morkunas 1996), except for 'Agila', which both in research conducted in Lithuania and in Poland produced fruits of a similar weight, i.e. about $4.5 \mathrm{~g}$.

The highest amount of mean dry matter content for the tested cultivars was observed in 2006 and the lowest in 2007 (Tab. 3). The lowest dry matter content was recorded for 'Agila'. In 2007 and 2008, 'Burlat' was one of the cultivars with a low content of this component.

The highest content of total saccharides was accumulated by fruits of the examined cultivars in 2008, and the lowest was in 2007. In 2006, differences between the cultivars were small. Significantly lower amounts of total saccharides in the fruit of the studied cultivars was observed in 2007, while in 2008 only 'Agila' fruit contained $9.05 \%$ of saccharides, with the other cultivars demonstrating a higher content of this component. The highest content of total saccharides was recorded for the 'Burlat' cultivar. However, the mean content during the three years of research for this cultivar was the lowest of all, and amounted to $7.09 \%$. The highest mean content of saccharides was observed for the 'Vasare' cultivar. The mean content of monosaccharides in the fruit of the tested cultivars slightly exceeded $4 \%$. It was the highest in 2008, while in 2006-2007 it remained at a similar level: $3.19 \%$ and $3.15 \%$, respectively. The lowest mean monosaccharide content was recorded for the fruit of the 'Jurgita' cultivar, $4.02 \%$, and the lowest was in the fruit of the 'Ulster' cultivar. According to Sitarek (2004), a mean content of saccharides in sweet cherry is $9-11 \mathrm{~g}$ per $100 \mathrm{~g}$ of fresh weight. In
2007, the amount of total saccharides in the fruits of the 'Seda', 'Ventenue', 'Jurgita' and 'Ulster' cultivars was almost two times smaller than the value provided by Sitarek (2004), and even three times for the 'Burlat' cultivar. On the other hand, the mean of the three years of research fit within the ranges provided in the literature. The concentration of chemical components in the fruit depends on the cultivar, soil and climatic conditions, tree treatment and the year of research; therefore, they cannot always be compared to analyses conducted in other laboratories.

A statistical analysis of the results concerning the content of organic acids in the fruit of the studied cultivars did not reveal any statistical differences between the years of research (Tab. 4). Cultivars that significantly differed in the amount of organic acids in fruits included 'Agila', with the highest content of this compound, and 'Seda', with the lowest value. According to Sitarek (2004), the content of organic acids, mainly apple and citric acid in sweet cherry fruit, ranged from 0.9 to $1.0 \mathrm{~g}$ in $100 \mathrm{~g}$ of fresh weight.

The vitamin $\mathrm{C}$ content significantly varied during the years of research (Tab. 4). The highest value of this compound was observed in 2006 and the lowest in 2007. The highest vitamin C content was recorded for fruit of the 'Agila' cultivar, with the lowest value for fruit of the 'Ulster' cultivar. Vitamin $\mathrm{C}$ content in sweet cherries is, on average, determined at the level of $5-10 \mathrm{mg} \%$ (Rozpara 1999, Sitarek 2004). The average vitamin C content in the fruit of the tested cultivars was consistent with the provided ranges. 


\section{CONCLUSIONS}

1. The highest mean yield for the tested cultivars was obtained in 2008 and the lowest was in 2007, when the most severe ground frosts were recorded in the cherry blossoming period. The highest mean yield during the three years of research amongst the Lithuanian sweet cherry cultivars was found for 'Vasare'.

2. The higher yields of Lithuanian cultivars, particularly 'Ventenue' in 2007 (during the least favourable weather conditions), as compared to the 'Burlat' and 'Ulster' cultivars, could be due to their higher frost-resistance.

3. The mean fruit weight of the Lithuanian cultivars was lower than in the case of 'Burlat' and 'Ulster', while the largest fruits amongst the Lithuanian cultivars were recorded for 'Jurgita' and 'Agila'.

4. An analysis of the chemical composition of the fruit revealed significant differences both between the cultivar and the years of research. Fruits of the tested cultivars accumulated the least amount of total saccharides and vitamin C in 2007 , the coldest year.

5. The highest content of mean total saccharides was recorded in fruits of the 'Vasare' cultivar, but fruits of the 'Agila' cultivar accumulated the highest amount of organic acids and vitamin C.

\section{ACKNOWLEDGEMENTS}

Sincere thanks are due to Prof. dr hab. Vidmantas Stanys for providing scions of Lithuanian cultivars analysed in the experiment.

\section{REFERENCES}

Bennewitz E., Sanhueza S., Elorriaga A., 2010. Effect of different crop load management strategies on fruit production and quality of sweet cherries (Prunus avium L.) 'Lapins' in central Chile. J. Fruit Ornam. Plant Res. 18(1): 51-57.

Bieniek A., Kawecki Z., Kopytowski J., Siksnianas T., 2009. Plonowanie oraz jakość owoców ukraińskich i litewskich odmian porzeczki czarnej w porównaniu z odmianą Titania. Zesz. Probl. Post. Nauk Roln. 536: 23-32.

Makosz E., 1999. Ekonomika nowoczesnej uprawy czereśni w Polsce. Zesz. Nauk. AR w Krakowie 351: 53-55.

MorkunAs A., 1996. Lituvos Pomologia, Vol. 2: 104-107. PN-90/A-75101/11., 1990. Przetwory owocowe i warzywne. Przygotowanie próbek i metody badań fizyko-chemicznych. Oznaczenie zawartości witaminy $\mathrm{C}$.

PN-90/A-75101/07., 1990. Przetwory owocowe i warzywne. Przygotowanie próbek i metody badań fizyko-chemicznych. Oznaczenie zawartości cukrów i ekstraktu bezcukrowego.

PN-90/A-75/101/04., 1990. Przetwory owocowe i warzywne. Przygotowanie próbek i metody badań fizyko-chemicznych. Oznaczenie kwasowości ogólnej.

Rozpara E., 1999. Nowoczesna uprawa czereśni. Hortpress, Warszawa.

Rozpara E., 2000. Czereśnia. Zeszyty Pomologiczne. Instytut Sadownictwa i Kwiaciarstwa, Skierniewice.

Rozpara E., GrZyb Z.S., 2006. The effect of the 'Northstar' intersterm on the growth, yielding and fruit quality of five sweet cherry cultivars. J. Fruit Ornam. Plant Res. 14: 91-96.

SitAReK M., 2004. Uprawa czereśni karłowych. Plantpress. Kraków.

Stanys V., Stanyte R., Staniene G., Vinskiene J., 2008. S-allele identification by PCR analysis in Lithuanian sweet cherries. Biologija. 54(1): 22-26.

Whiting M.D., Ophardt D., 2005. Comparing novel sweet cherry crop load management strategies. Hortscience 20(5): 1271-1275.

Whiting M., Ophardt D., Mcferson J., 2006. Chemical blossom thinners vary in their effect on sweet cherry fruit set, yield, fruit quality, and crop value. HortTechnology 16: 66-70.

Wociór S., 2008. The effect of rootstock on the growth and yield of 'Regina' cherry trees. Folia Hort. 20/1: $15-22$.

\section{PLONOWANIE I JAKOŚĆ OWOCÓW \\ LITEWSKICH ODMIAN CZEREŚNI \\ UPRAWIANYCH W WARUNKACH \\ KLIMATYCZNO-GLEBOWYCH WARMII}

Streszczenie: W latach 2006-2008 określono plonowanie, wykonano biometrię oraz analizy chemiczne owoców pięciu litewskich odmian czereśni: 'Agila', 'Seda', 'Vasare', 'Ventenue', 'Jurgita' oraz dwóch powszechnie uprawianych w Polsce: 'Ulster' i 'Burlat'. Drzewa szczepione na czereśni ptasiej posadzono w 2002 r. w sadzie Zakładu Produkcyjno-Doświadczalnego „Pozorty” we wsi Łęgajny niedaleko Olsztyna. Najwyższe średnie plony dla badanych odmian uzyskano $\mathrm{w}$ 2008 roku, a najniższe w 2007 roku, w którym zanotowano największe przymrozki w okresie kwitnienia czereśni. Najwyższym średnim plonem z 3 lat badań spośród litewskich odmian czereśni charakteryzowała się odmiana 'Vasare', która wraz z odmianą 'Burlat' tworzyła grupe jednorodna o najwyższych wartościach. Średnia masa owoców odmian litewskich była niższa od 'Burlat' oraz 'Ulster', największymi owocami spośród 
litewskich odmian charakteryzowała się odmiana 'Jurgita' i 'Agila'. Analiza składu chemicznego owoców wykazała istotne różnice zarówno między odmianami jak i w latach badań. Najmniej cukrów ogółem oraz witaminy C zgromadziły owoce badanych odmian w najchłodniejszym - 2007 roku. Najwyższą średnią zawartość cukrów ogółem zanotowano w owocach odmiany 'Vasare' oraz 'Seda'. Najwięcej kwasów organicznych oraz witaminy C zgromadziły owoce odmiany 'Agila'.

Received December 6, 2010; accepted November 16, 2011 